\title{
Edukasi Covid-19 dan Social Distancing Kepada Kelompok Warga Penerima Bantuan Program Keluarga Harapan (PKH) Di Kelurahan Surabaya Kota Bengkulu
}

\author{
Dalifa Dalifa $^{1}$, Sri Ken Kustianti ${ }^{2}$, Neza Agusdianita ${ }^{3}$, Dwi Anggraini ${ }^{4}$ \\ ${ }^{1234}$ Universitas Bengkulu \\ Email: dalifa@unib.ac.id
}

\begin{tabular}{ll}
\hline Article History: & Abstrak: \\
Received: Desember & Pada masa pandemi virus covid-19 ini \\
2020 & masyarakat membutuhkan edukasi agar dapat \\
Revised: Januari 2021 & terhindar dari paparan virus ini. Tujuan dari \\
Accepted: Juni 2021 & kegiatan ini adalah untuk memberikan edukasi \\
Available online: Juni & Covid-19 dan social distancing kepada \\
2021 & kelompok warga penerima bantuan progam \\
& keluarga harapan (PKH) di Kelurahan \\
& Surabaya Kota Bengkulu. Metode yang \\
& digunakan pada kegiatan PPM ini adalah \\
Kata Kunci: & pendampingan kepada masyarakat sasaran \\
Covid-19, Social & melalui grup whatsapp dan dilengkapi dengan \\
distancing, Program & buku saku. Instrumen yang digunakan dalam \\
Keluarga Harapan & kegiatan PPM ini adalah lembar angket \\
& pemahaman masyarakat sasaran mengenai \\
& Covid-19 dan social distancing. Analisis data \\
& kegiatan ini secara deskriptif kualitatif. Hasil \\
& penelitian ini ialah telah terlaksana kegiatan \\
& pendampingan edukasi Covid-19 dan social \\
& distancing kepada kelompok warga penerima \\
& bantuan progam keluarga harapan (PKH) di \\
& Kelurahan Surabaya Kota Bengkulu dengan \\
& baik. Terdapat peningkatan pemahaman warga \\
& mengenai wabah Covid-19 dan social \\
& distancing melalui kegiatan pendampingan \\
dengan grup whatsapp dilengkapi dengan \\
buku saku mengenai Covid-19. Luaran dari \\
kegiatan ini adalah publikasi pada jurnal, buku \\
saku dan publikasi video kegiatan di youtube \\
channel. \\
\\
\end{tabular}




\section{Pendahuluan}

Indonesia bahkan seluruh belahan dunia sejak awal tahun 2020 digemparkan oleh Covid-19. Di Indonesia penularannya cukup cepat dengan jumlah peningkatan pasien yang sangat signifikan serta angka kematian yang tinggi (Karimuna, 2020). Pandemi Covid-19 berdampak luas pada berbagai bidang, termasuk pada usaha kecil dan menengah (Irawan, 2020). Indonesia sendiri telah berjuang untuk melawan virus tersebut. Pemerintah telah memberikan himbauan-himbauan kepada masyarakat dalam mengatasi wabah ini agar berjalan efektif dan efisien. Tetapi pada kenyataannya masih banyak masyarakat Indonesia yang tidak mengindahkan himbauan ini (Buana, 2020). Hasil pengabdian Prayitno (2020) menyatakan bahwa warga yang tidak memakai masker ada beberapa alasan karena tidak mau membeli, tidak nyaman memakai masker dan bahkan ada yang mengatakan belum mengerti. Sehingga diperlukan adanya edukasi dan informasi mengenai virus ini kepada warga masyarakat.

Kelompok warga yang menjadi sasaran mitra program PPM penerapan Ipteks kali ini yaitu warga penerima bantuan program keluarga harapan (PKH) kelompok 8 kelurahan Surabaya Kecamatan Sungai Serut Kota Bengkulu. Penerima bantuan PKH adalah Rumah Tangga Sangat Miskin (RTSM) yang memiliki anggota keluarga yang terdiri dari anak usia 0-15 tahun dan/atau ibu hamil/nifas dan berada pada lokasi terpilih. Penerima bantuan adalah lbu atau wanita dewasa yang mengurus anak pada rumah tangga yang bersangkutan (jika tidak ada lbu maka: nenek, tante/ bibi, atau kakak perempuan dapat menjadi penerima bantuan).

Semenjak mewabahnya Covid-19 ini warga PKH merupakan salah satu yang terkena dampaknya. Kepala keluarganya tidak bisa bekerja karena tempatnya bekerja menghentikan sementara kegiatan kontruksi atau proyek yang sedang dikerjakan. Sementara itu roda kehidupan mereka tetap harus berjalan. Biaya hidup mereka tidak berkurang, biaya sekolah anak tetap harus dibayarkan. Sebagian lagi yang bekerja berjualan di pasar tidak bisa mengikuti anjuran pemerintah untuk diam di rumah saja. Mereka tetap harus berjualan 
untuk makan. Namun sangat disayangkan sedikit sekali yang patuh dan sadar untuk menggunakan masker dan social distancing selama bekerja di luar rumah. Alasan mereka sederhana yaitu mereka lebih memilih untuk membeli beras daripada membeli masker untuk dipakai saat berjualan.

Berdasarkan fenomena yang terjadi tersebut maka tim dosen dari Fkip Unib tergerak hati untuk melakukan kegiatan pengabdian yaitu Edukasi Mengenai Covid-19 dan social distancing Kepada Kelompok Warga Penerima Bantuan Program Keluarga Harapan (PKH) di Kelurahan Surabaya Kota Bengkulu. Kegiatan ini dimulai dengan memberikan buku saku mengenai Covid-19 dan social distancing, pemberian masker dan pemberian paket sembako kepada warga kelompok 8 PKH kelurahan Surabaya. Diharapkan dari kegiatan PPM ini dapat membantu pemerintah mencegah penularan Covid-19 dan membantu warga yang terkena dampak dari mewabahnya Covid-19. Selanjutnya melalui kegiatan ini dapat menambah citra baik bagi universitas Bengkulu.

\section{Metode}

Metode yang digunakan pada kegiatan PPM ini adalah pendampingan kepada warga PKH. Setiap warga didampingi oleh tim dosen pengabdian mengenai edukasi dan informasi tentang Covid-19 ini. Kegiatan ini dimulai dari tanggal 21 September 2021. Kegiatan diawali dengan koordinasi dengan pendamping kelompok PKH. Kemudian dilanjutkan dengan membagikan masker dan kuesioner. Dan diakhiri dengan pertemuan diskusi dengan tim pengabdi mengenai virus covid-19. Tim dosen akan memberikan buku saku tentang Covid-19, penularannya, upaya pencegahan penularan dan social distancing. Selanjutnya akan dibuatkan grup whatsapp (WAG) untuk berdiskusi dan berbagi informasi mengenai masalah wabah Covid-19 ini. Hasil penelitian menunjukkan bahwa budaya media sosial di Indonesia dapat bertindak sebagai guru yang mampu mengedukasi masyarakat dan menstimulasi dalam penelitian terbaru terkait Covid-19 (Sampurno, 2020).

Pihak yang terkait dalam kegiatan PPM ini Bapak pendamping PKH, yang merupakan petugas dari pemerintah untuk mendampingi kegiatan $\mathrm{PKH}$ 
setiap bulannya, selain itu juga melibatkan Bapak Lurah kelurahan Surabaya. Semua pihak saling memberikan sumbangsih untuk pelaksanaan kegiatan ini. Diharapkan kegiatan ini dapat memberikan sumbangan kontribusi terhadap upaya pencegahan penularan Covid-19. Untuk mengevaluasi keberhasilan kegiatan pengabdian pada masyarakat digunakan metode sebagai berikut: Untuk mengevaluasi keberhasilan kegiatan pendampingan tim dosen pengabdian membuat lembar angket yang diisi oleh setiap warga $\mathrm{PKH}$. Angket tersebut merupakan alat untuk menilai pemahaman warga $\mathrm{PKH}$ mengenai wabah Covid-19 dan social distancing.

\section{Hasil}

Kegiatan PPM ini dilaksanakan sejak tangal 21 September 2020 sampai dengan 12 Oktober 2020. Kegiatan ini dilaksanakan secara online via Wa dan pertemuan akhir satu kali untuk diskusi dan pembagian sembako. Tim dosen pengabdi memberikan edukasi dan informasi mengenai wabah Covid19 ini melalui buku saku yang diberikan kepada warga PKH dan didampingi juga melalui grup whatsapp untuk wadah diskusi dengan mitra sasaran. Kegiatan ini dilakukan melalui daring . Pada tahap edukasi melalui daring ini tim dosen mengirimkan video dan gambar mengenai Covid-19. Melalui media daring juga warga PKH dan dosen saling bertukar informasi, berdiskusi mengenai masa pandemi ini dan langkah-langkah apa saja yang harus dilakukan agar terhindar dari virus ini.

Kegiatan ini ditutup dengan pertemuan akhir dengan mitra sasaran yaitu warga PKH, Bapak pendamping PKH kelurahan Surabaya dan tim dosen serta beberapa mahasiswa. Pada pertemuan ini tim dosen kembali menyampaikan materi singkat mengenai wabah Covid-19 dan upaya agar terhindar dari virus ini. Selain itu juga melakukan diskusi dan pemantapan pemahaman warga PKH mengenai wabah Covid-19. Di akhir pertemuan ini tim dosen membagikan paket sembako kepada masing-masing warga penerima bantuan PKH kelurahan Surabaya Kota Bengkulu. 


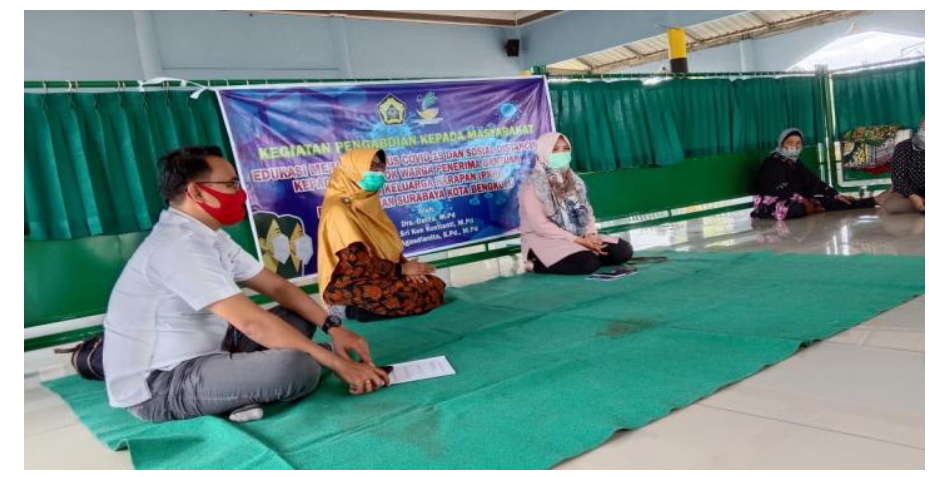

Gambar 1. Tim dosen menyampaikan materi mengenai Covid-19 kepada warga PKH

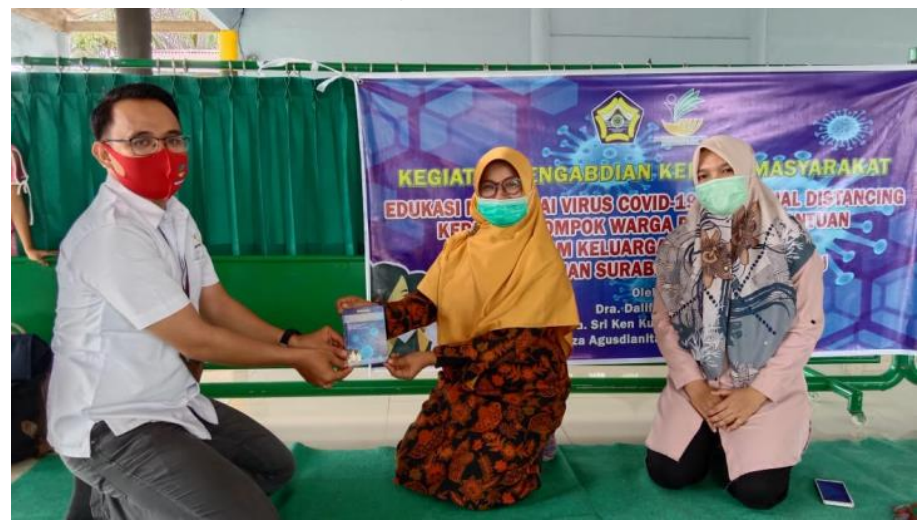

Gambar 2. Tim dosen memberikan buku saku secara simbolis kepada Bapak pendamping PKH kelurahan Surabaya Kota Bengkulu

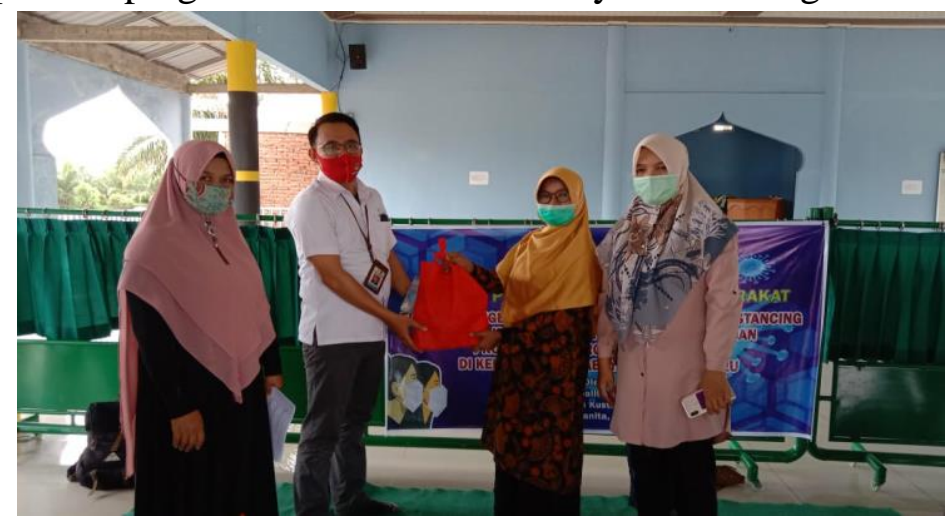

Gambar 3. Tim dosen memberikan paket sembako secara simbolis kepada Bapak Pendamping PKH dan Ibu Ketua PKH kelurahan Surabaya Kota Bengkulu 


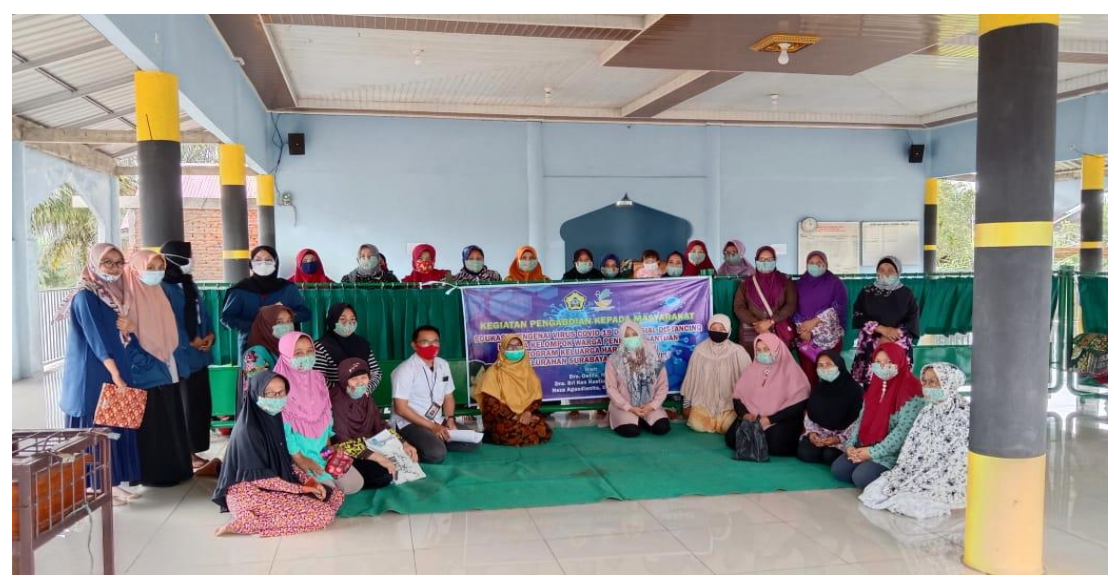

Gambar 4. Foto bersama dengan tim dosen, mitra sasaran warga PKH dan mahasiswa

Untuk mengevaluasi kegiatan PPM ini maka tim dosen memberikan angket kepada mitra sasaran yaitu warga PKH. Angket tersebut untuk mengetahui keberhasilan dari kegiatan PPM yang dilaksanakan. Angket berisi pertanyaan-pertanyaan mengenai wabah Covid-19 dan social distancing. Angket tersebut berisi pertanyaan-pertanyaan mengenai cara penularan virus, gejala virus, cara mencegah penularan virus, dan mengenai social distancing. Angket diisi oleh seluruh anggota kelompok berjumlah 20 orang. Angket diberikan dua kali, yang pertama sebagai tes pemahaman awal sebelum diberikan edukasi oleh tim pengabdi. Selanjutnya diakhir kegiatan tim dosen kembali memberikan angket kepada warga PKH. Hasil analisis dari data isian angket menunjukkan terdapat peningkatan skor pemahaman warga PKH mengenai Covid-19 dan social distancing. Rata-rata skor pretest adalah 78 meningkat menjadi 90 pada skor rata-rata posttest. Berdasarkan hasil penelitian (Purnamasari, 2020) bahwa terdapat hubungan bermakna antara pengetahuan dengan perilaku masyarakat tentang Covid-19 dengan $p$-value 0,047. Dengan demikian kegiatan PPM ini yang meningkatkan pengetahuan warga PKH berdampak positif juga dengan perilaku dalam menghadapi wabah Covid-19. 


\section{Diskusi}

Corona virus adalah keluarga besar virus yang menyebabkan penyakit mulai dari gejala ringan sampai berat. Ada setidaknya dua jenis coronavirus yang diketahui menyebabkan penyakit yang dapat menimbulkan gejala berat seperti Middle East Respiratory Syndrome (MERS) dan Severe Acute Respiratory Syndrome (SARS) (Direktorat jendral pencegahan dan pengendalian penyakit. 2020). Virus Corona bisa menyebabkan gangguan ringan pada sistem pernapasan, infeksi paru-paru yang berat, hingga kematian. Severe acute respiratory syndrome coronavirus 2 (SARS-CoV-2) yang lebih dikenal dengan nama virus Corona adalah jenis baru dari coronavirus yang menular ke manusia. Walaupun lebih banyak menyerang lansia, virus ini sebenarnya bisa menyerang siapa saja, mulai dari bayi, anak-anak, hingga orang dewasa, termasuk ibu hamil dan ibu menyusui.

Ada beberapa gejala lain yang juga bisa muncul pada infeksi virus Corona meskipun lebih jarang, yaitu: diare, sakit kepala, konjungtivitis, hilangnya kemampuan mengecap rasa atau mencium bau, dan Ruam di kulit. Gejala-gejala COVID-19 ini umumnya muncul dalam waktu 2 hari sampai 2 minggu setelah penderita terpapar virus Corona. Masyarakat masih ada yang belum waspada dengan gejala-gejala virus ini yang relatif sama dengan gejala virus influenza atau penyakit tifus. Terutama masyarakat yang ada pada kalangan ekonomi rendah yang enggan mengeluarkan uang untuk sekedar memeriksakan diri ke fasillitas kesehatan.

Mitra dalam kegiatan PPM ini adalah warga masyarakat yang menerima bantuan program keluarga Harapan di kelurahan Surabaya kota Bengkulu. Program keluarga Harapan (PKH) merupakan suatu program penanggulangan kemiskinan. PKH berada di bawah koordinasi Tim Koordinasi Penanggulangan Kemiskinan (TKPK), baik di Pusat maupun di daerah. Temuan penelitian menunjukkan efektifitas program pemerintah khususnya bagi masyarakat miskin dirasakan sangat bermanfaat bagi mereka, dan sebagian besar masyarakat mendukung program yang dilakukan oleh pemerintah pusat tersebut (Maun, 2020). 
Tujuan utama dari PKH adalah untuk mengurangi kemiskinan dan meningkatkan kualitas sumberdaya manusia terutama pada kelompok masyarakat miskin. Tujuan tersebut sekaligus sebagai upaya mempercepat pencapaian target MDGs. Secara khusus, tujuan PKH terdiri atas: (1) Meningkatkan kondisi sosial ekonomi RTSM; (2) Meningkatkan taraf pendidikan anak-anak RTSM; (3) Meningkatkan status kesehatan dan gizi ibu hamil, ibu nifas, dan anak di bawah 6 tahun dari RTSM; (4) Meningkatkan akses dan kualitas pelayanan pendidikan dan kesehatan, khususnya bagi RTSM.

Sasaran atau Penerima bantuan PKH adalah Rumah Tangga Sangat Miskin (RTSM) yang memiliki anggota keluarga yang terdiri dari anak usia 0-15 tahun dan/atau ibu hamil/nifas dan berada pada lokasi terpilih. Penerima bantuan adalah lbu atau wanita dewasa yang mengurus anak pada rumah tangga yang bersangkutan (jika tidak ada lbu maka: nenek, tante/ bibi, atau kakak perempuan dapat menjadi penerima bantuan). Jadi, pada kartu kepesertaan PKH pun akan tercantum nama ibu/wanita yang mengurus anak, bukan kepala rumah tangga. Untuk itu, orang yang harus dan berhak mengambil pembayaran adalah orang yang namanya tercantum di Kartu PKH.

Kegiatan PPM ini bertujuan untuk memberikan edukasi kepada warga kelompok PKH mengenai wabah Covid-19 dan social distancing agar penyebaran Covid-19 bisa dihentikan, membagikan masker gratis kepada masing-masing warga kelompok PKH sebagai upaya untuk pencegahan penularan Covid-19 dan memberikan bantuan paket sembako untuk meringankan sedikit beban ekonomi yang dihadapi oleh warga PKH tersebut.

Kegiatan semacam ini pernah juga dilakukan oleh Listina (2020) hasil dari kegiatan PPM, dilakukan kegiatan pemberian informasi dan penempelan poster-poster mengenai Covid-19. Selain itu juga ada yang melalui video edukasi tentang Covid-19 yang diunggah di YouTube, yang nantinya mampu memberikan edukasi yang lebih luas di kalangan pengguna YouTube. Respon yang diberikan warga pun cukup antusias, mengingat cukup banyak warga desa yang bersedia ikut dalam program edukasi tersebut (Segara, 2020).

Berdasarkan hasil evaluasi kegiatan yang telah dilakukan maka dapat 
disimpulkan kegiatan ini telah berhasil dengan baik. Terdapat peningkatan pemahaman warga mengenai Covid-19 ini. Sejalan dengan pemahaman warga yang baik tersebut diharapkan juga berdampak pada perilaku dan sikap warga dalam menghadapi pandemi Covid-19 ini nantinya.

\section{Kesimpulan}

Simpulan dari kegiatan ini adalah telah terlaksana kegiatan pengabdian kepada masyarakat yaitu memberikan edukasi Covid-19 dan social distancing kepada kelompok warga penerima bantuan progam keluarga harapan (PKH) di Kelurahan Surabaya Kota Bengkulu. Hasil kegiatan ini menunjukkan adanya peningkatan pemahaman warga PKH tentang wabah Covid-19 dan upaya untuk terhindar dari virus ini.

Saran dari kegiatan pengabdian ini adalah memberikan edukasi mengenai Covid-19 ini secara berkesinambungan karena warga butuh diberikan informasi terkini dan hal-hal apa saja yang perlu dilakukan selanjutnya dalam menghadapi pandemi wabah Covid-19 ini.

\section{Pengakuan/Acknowledgements}

Kegiatan PPM ini terlaksana atas dukungan dan Kerjasama berbagai pihak. Kegiatan PPM ini terlaksana melalui kegiatan hibah pengabdian berbasis IPTEK dari FKIP Universitas Bengkulu dengan nomor kontrak 9731/UN30/KU/2020 yang diketuai oleh Dra. Dalifa, M.Pd. Ucapan terima kasih disampaikan kepada Dekan FKIP Universitas Bengkulu yang telah memberikan fasilitas dan dukungan baik moril maupun materil, Bapak pendamping PKH kelurahan dan mitra PPM Kelompok Warga Penerima Bantuan Program Keluarga Harapan (PKH) Di Kelurahan Surabaya.

\section{Daftar Referensi}

Buana, D. R. (2020). Analisis perilaku masyarakat indonesia dalam menghadapi pandemi virus corona (Covid-19) dan kiat menjaga kesejahteraan jiwa. Jurnal Sosial dan Budaya Syar'I, 7(3), 217-226.

Direktorat Jendral Pencegahan dan Pengendalian Penyakit. (2020). Pedoman kesiapsiagaan menghadapi coronavirus disease (Covid-19). Jakarta. Kementerian Kesehatan RI Direktorat Jenderal Pencegahan dan Pengendalian Penyakit (P2P). 
Irawan, D. (2020). Neni triana, linda suwarni, selviana selviana. Edukasi Protokol Kesehatan Dan Strategi Pemasaran Online Melalui Program Kemitraan Masyarakat Di Era Pandemi Covid-19. Jurnal masyarakat Mandiri, 4(4), 655-661.

Karimuna, S. R. (2020). Sosialisasi Gerakan Social Distancing Dan Penerapan Psikologi Positif Dalam Rangka Pencegahan Dan Pengendalian Penyebaran Covid-19 Di Kelurahan Tondongeu, Kota Kendari, Provinsi Sulawesi Tenggara. Jurnal Anoa, 12(1), 53-62.

Listina, O. dkk. (2020). Edukasi Corona Virus Desease 19 (Covid-19) Melalui Penyebaran Poster Kepada Masyarakat Kecamatan Slawi Kabupaten Tegal. Jabi: Jurnal Abdimas Bhakti Indonesia, 1(2).

Maun, C. E. F. (2020). Efektivitas Bantuan Langsung Tunai Dana Desa Bagi Masyarakat Miskin Terkena Dampak Covid-19 Di Desa Talaitad

Kecamatan Suluun Tareran Kabupaten Minahasa Selatan. Jurnal Politico, 9(2), 1-16.

Prayitno, S. A. dkk. (2020). Peran Serta Dalam Melaksanakan Protokol Pencegahan Penyebaran Corona Virus Disease (Covid-19) Pada Masyarakat. Dedikasimu (Journal of Community Service), 2(3), 504510.

Purnamasari, I. \& Anisa, E. R. (2020). Tingkat Pengetahuan Dan Perilaku Masyarakat Kabupaten Wonosobo Tentang Covid -19. Jurnal Ilmiah Kesehatan, 10(1), 33-42.

Sampurno, M. B. T, dkk. (2020). Budaya Media Sosial, Edukasi Masyarakat

Dan Pandemi Covid-19. Jurnal Sosial \& Budaya Syar-I, 7(6), 529-542.

Segara, W. Jurnal Hasil Penelitian dan Pengabdian Masyarakat, 8(2),108113. 